\title{
Task Commitment pada Mahasiswa Suku Bugis yang Merantau
}

\author{
Andi Ahmad Ridha ${ }^{1}$ \\ Fakultas Psikologi Universitas Airlangga
}

\begin{abstract}
Settled foreigner college students' task commitment becomes an important issue due to the demands to commit to themselves and to complete academic tasks. This study uses a quantitatve approach and aims to perceive the effect of autonomy towards task commitment on college students of Bugis tribe setteled foreigner. The participants in this study are 96 college students of Bugis tribe. Data were collected using autonomy scale and task commitment scale. Results shows that autonomy is a contributive factor towards task commitment with an amount up to $39,1 \%$ and the remnant is followed by other factors. The Bugis tribe settled foreigner college students has a high task commitment with an amount up to $62.5 \%$ and moderate task commitment with an amount up to $37.5 \%$. Autonomy in college students has an effect towards the degree of task commitment on the Bugis tribe college students.
\end{abstract}

Keywords: autonomy; bugis tribe; task commitment; settled foreigner college students

\begin{abstract}
Abstrak. Task commitment pada mahasiswa yang merantau menjadi penting karena mahasiswa dituntut untuk dapat berkomitmen pada diri sendiri dalam tugas-tugas dan menyelesaikan tuntutan akademik di perguruan tinggi. Penelitian ini merupakan penelitian kuantitatif yang bertujuan untuk mengetahui pengaruh kemandirian terhadap task commitment pada mahasiswa suku Bugis yang merantau. Pengambilan data dilakukan dengan menyebarkan skala kemandirian dan task commitment pada 96 orang mahasiswa suku Bugis yang merantau. Hasil analisis menunjukkan bahwa kemandirian memiliki sumbangan efektif terhadap variabel task commitment sebesar 39,1\% dan selebihnya dipengaruhi oleh faktor lain. Mahasiswa suku Bugis yang merantau berada pada kategori task commitment yang tinggi sebesar $62,5 \%$, dan $37,5 \%$ pada kategori task commitment sedang. Mahasiswa yang memiliki kemandirian berpengaruh terhadap tingginya task commitment yang dimiliki mahasiswa suku Bugis di perantauan.
\end{abstract}

Kata kunci: task commitment; kemandirian; mahasiswa rantau; suku Bugis

Merantau merupakan suatu kondisi yang dialami ketika mahasiswa memilih untuk melanjutkan pendidikan di luar lingkungan tempat tinggalnya. Mahasiswa yang memilih merantau, pada dasarnya memiliki tujuan untuk mendapatkan

\footnotetext{
${ }^{1}$ Korespondensi mengenai artikel ini dapat melalui: ridho.abdillah92@gmail.com
}

kualitas pendidikan yang lebih baik yang tidak didapatkan di daerah asalnya. Tanpa komitmen yang kuat, maka tujuan awal mahasiswa untuk mendapatkan kualitas pendidikan yang lebih baik akan sulit dicapai.

Mahasiswa yang merantau akan menemukan beragam perbedaan antara 
kondisi lingkungan tempat tinggal dan kondisi lingkungan di perantauan. Mahasiswa dihadapkan dengan berbagai perbedaan dalam setiap aspek kehidupan, seperti perbedaan pola hidup, kebiasaan, bahasa, dan interaksi sosial. Mahasiswa yang memilih untuk merantau memiliki tanggung jawab yang lebih besar terhadap tindakan-tindakan yang dilakukan sehingga mahasiswa dituntut untuk menyesuaikan diri di lingkungan yang asing baginya. Oleh karena itu, mahasiswa di perantauan dituntut untuk memiliki penyesuaian diri yang mumpuni. Hal ini karena di lingkungan perantauan terjadi perubahan pola hidup, kebudayaan, bahasa, serta tuntutan untuk hidup mandiri (Shafira, 2015).

Sifat merantau adalah ciri khas yang dimiliki mayoritas orang Bugis dalam hal perniagaan, pekerjaan, dan menuntut ilmu. Suku Bugis merupakan salah satu dari berbagai suku bangsa di Asia Tenggara dengan populasi lebih dari 8.000 .000 orang. Mereka mendiami bagian barat daya Pulau Sulawesi. Mereka termasuk ke dalam rumpun keluarga besar Austronesia. Bagi suku-suku lain di sekitarnya, orang Bugis dikenal sebagai orang yang berkarakter keras dan sangat menjunjung tinggi kehormatan. Namun dibalik sifat keras itu, orang Bugis juga dikenal sebagai orang yang ramah dan sangat menghargai orang lain serta sangat tinggi rasa kesetiakawanannya (Pelras, 2006).

Dalam kehidupan masyarakat Bugis sendiri, interaksi sehari-hari pada umumnya berdasarkan sistem kelompok kesetiakawanan yang saling menghargai dan menghormati satu sama lainnya. Namun demikian, mereka tetap memiliki rasa kepribadian yang kuat. Meskipun orang Bugis merupakan salah satu suku yang memiliki sistem hierarkis paling rumit dan tampak kaku, akan tetapi pada sisi lain, prestise dan hasrat berkompetisi untuk mencapai kedudukan sosial tinggi, baik melalui jabatan, pendidikan, maupun kekayaan, tetap merupakan faktor pendorong utama yang menggerakkan roda kehidupan sosial-kemasyarakatan mereka (Pelras, 2006).

Ciri khas yang saling berlawanan itulah yang membuat orang Bugis memiliki mobilitas sangat tinggi serta memungkinkan mereka menjadi perantau. Di seluruh wilayah Indonesia, dari semenanjung Melayu dan Singapura hingga pesisir barat Papua, dari Filipina Selatan dan Kalimantan Utara hingga Nusa Tenggara, dapat dijumpai orang Bugis yang sibuk dengan beragam aktivitas seperti pelayaran, perdagangan, pertanian, pembukaan lahan perkebunan di hutan, menuntut ilmu, atau pekerjaan apa saja yang mereka anggap sesuai dengan kondisi ruang dan waktu. Kemampuan orang Bugis untuk berubah dan menyesuaikan diri merupakan modal terbesar mereka dapat bertahan dimana-mana selama berabad-abad. Walau mereka terus menyesuaikan diri dengan keadaan sekitarnya, orang Bugis ternyata tetap mampu mempertahankan identitas kebugisannya (Pelras, 2006).

Suatu pepatah masyarakat Bugis yang berbunyi "sekali layar terkembang, pantang biduk surut ke pantai" yang melambangkan bahwa suku Bugis memiliki keberanian dalam menjalani kehidupan dengan prinsip yang penuh kearifan, kebijaksanaan, dan perhitungan yang matang (Rayesa, 2013). Hal ini terinternalisasi dalam diri mahasiswa perantau suku Bugis, berdasarkan wawancara awal terhadap lima orang mahasiswa, diketahui bahwa mahasiswa senantiasa berupaya untuk melakukan yang terbaik dalam menempuh pendidikan di tanah rantauan dan tidak akan kembali ke kampung halaman 
sebelum meraih gelar akademik yang dicita-citakannya. Hal ini mengindikasikan pentingnya nilai mengenai task commitment akademik dalam menuntut ilmu yang dimiliki mahasiswa perantau suku Bugis.

Pada penelitian Solihin (2013) menunjukkan bahwa perantau suku Bugis memiliki kegigihan yang tinggi dalam bertahan hidup dan beradaptasi di lingkungan baru. Penelitian ini menjelaskan bahwa mahasiswa perantau memanfaatkan beasiswa untuk melanjutkan pendidikannya ke Melbourne. Merantau menjadi tantangan bagi mahasiswa tersebut karena ia dituntut untuk mampu beradaptasi dengan lingkungan alam yang mengalami empat musim serta lingkungan sosial-budaya yang beragam. Di tengah kehidupan yang serba modern dan majemuk, mahasiswa berusaha bertahan meskipun pada akhirnya harus mengalami berbagai perubahan. Penelitian ini menunjukkan adanya komitmen yang dimiliki oleh mahasiswa dalam menempuh pendidikan dengan melakukan berbagai strategi dalam beradaptasi untuk mencapai suatu tujuan.

Secara sederhana, Renzulli mengemukakan bahwa task commitment merupakan suatu komitmen terhadap tugas, kemampuan dalam menyelesaikan tugas yang ditandai dengan adanya ketekunan, kerajinan, etos kerja yang tinggi, percaya diri, dan adanya keyakinan akan kemampuannya dalam menyelesaikan suatu pekerjaan (Syarifah, Mustami'ah, \& Sulistiani, 2011). Sementara itu, menurut Firmanto (2013) bahwa task commitment merupakan hal yang sangat penting untuk dimiliki karena memiliki kontribusi yang besar dalam meningkatkan prestasi akademik individu.

Penelitian yang dilakukan oleh Kim, Byeon, dan Kwon (2012) menunjukkan bahwa task commitment yang dimiliki mahasiswa berbeda-beda, 1) task goal commitment, yaitu komitmen terhadap tujuan yang telah ditetapkan yang disertai dengan harapan yang tinggi; 2) low goal commitment, yaitu komitmen yang rendah pada tujuan, tugas yang dikerjakan seadanya, dan memiliki penguasaan yang rendah; 3) conditional commitment, yaitu komitmen yang rendah pada tugas, prestasi yang dihasilkan rendah atau berhenti mengerjakan tugas sebelum memperoleh hasil; 4) suspended commitment, yaitu harapan yang rendah disertai dengan tujuan yang rendah pula dan 5) delayed commitment, yaitu harapan yang rendah tanpa disertai tujuan yang jelas sehingga menyebabkan mahasiswa mudah putus asa.

Selain itu, penelitian Vaidya (2012) menunjukkan bahwa dalam belajar dibutuhkan komitmen yang kuat dan kepercayaan diri yang tinggi untuk mencapai tujuan pembelajaran yang telah ditetapkan. Penelitian Winata (2014) menunjukkan bahwa bagi mahasiswa yang merantau agar dapat mencapai prestasi akademik, maka ia harus disiplin mengikuti aturan perkuliahan, aktif sebagai pembelajar dengan mengerjakan tugas kuliah dan memiliki motivasi. Hal ini menunjukkan bahwa task commitment sangat dibutuhkan oleh mahasiswa agar dapat meraih kesuksesan di perantauan.

Renzulli mengemukakan bahwa task commitment merupakan wujud dari adanya motivasi yang dimiliki individu dalam menyelesaikan suatu tugas (Syarifah, Mustami'ah, \& Sulistiani, 2011). Oleh karena itu, agar dapat menjalankan fungsi task commitment dengan baik maka individu harus memiliki kemandirian sebagai mahasiswa di perantauan.

Individu yang mandiri mampu memotivasi dirinya untuk bertahan 
dengan kesulitan yang dihadapi dan dapat menerima kegagalan dengan pikiran yang rasional. Individu yang mandiri adalah individu yang percaya akan kemampuan dan memiliki prinsip dalam hidupnya sehingga ia akan mampu melakukan aktivitas apapun dalam hidupnya tanpa harus bergantung pada orang lain. Individu yang mandiri akan memperlihatkan perilaku yang eksploratif, mampu mengambil keputusan, percaya diri, dan kreatif. Selain itu, ia juga mampu bertindak kritis, menunjukkan keberanian, mempunyai kepuasan dalam melakukan aktivitasnya, fleksibel, dan mampu menerima realitas. Kebutuhan untuk memiliki kemandirian dipercaya sebagai hal yang penting dalam memperkuat motivasi individu (Wijaya, 2015).

Kemandirian harus dimiliki oleh individu agar dapat mengembangkan diri dengan mengeksplorasi potensi tanpa harus ada pengekangan dari orang lain. Hal ini menjadi penting bagi individu agar mampu mengambil keputusan secara mandiri di masa yang akan datang dan menjalin relasi sosial yang lebih luas (Fleming, 2005). Kemandirian berperan penting bagi mahasiswa yang berada dalam lingkungan akademis yang baru. Mahasiswa dituntut untuk mandiri, gigih, dan fleksibel dalam menghadapi perubahan kehidupan sosial, maupun akademisnya. Hal ini tentunya sangat diperlukan bagi mahasiswa perantau yang jauh dari lingkungan keluarga dan tempat tinggalnya. Mahasiswa jauh dari keluarga dan teman-teman yang merupakan sumber dukungan sosialnya (Warsito, 2013).

Renzulli mengemukakan bahwa task commitment merupakan perwujudan dari motivasi internal yang berada dalam diri individu sehingga individu memiliki ketekunan yang tinggi dalam menyelesai- kan suatu tugas (Tiel \& Widyorini, 2014). Komitmen untuk meningkatkan diri merupakan implementasi dari tujuan yang menantang sehingga akan menarik minat dan keterlibatan individu dalam beraktivitas (Santrock, 2007). Individu yang memiliki komitmen, akan merasa tertantang untuk mengatasi situasi yang sulit dan senantiasa berusaha untuk mencapai keberhasilan (Ghufron \& Risnawita, 2011). Task commitment merupakan suatu ketekunan dalam mengerjakan tugas yang tercermin dari perilaku individu seperti disiplin, kerja keras, teguh, dan pantang menyerah (Syarifah, Mustami'ah, \& Sulistiani, 2011). Komitmen yang tinggi membawa dampak positif bagi individu yaitu ia akan memperhatikan tugasnya. Hal inilah yang disebut sebagai task commitment (Elias, 1985).

Kanter mengemukakan bahwa task commitment dilakukan dengan cara mengerahkan seluruh energi yang dimiliki untuk mengerjakan suatu tugas (Elias, 1985). Individu dapat belajar dengan mengikuti keinginan diri sendiri yang disertai pola-pola pembelajaran yang positif. Adanya hal positif yang dirasakan, membuat individu tertarik dan berkomitmen untuk mengembangkan diri ke arah yang lebih baik (Scott, 2006). Kiesler mengemukakan bahwa task commitment merupakan suatu hal yang menjamin dan mengikat individu dalam mengerjakan tugas. Lebih lanjut dijelaskan bahwa yang mengikat dari suatu tindakan untuk diri sendiri disamakan dengan perasaan tanggung jawab atas tindakan tersebut (Elias, 1985).

Komitmen dapat mengungkapkan keterkaitan antara sikap dan perilaku. Hal ini dapat diartikan sebagai hubungan antara komitmen dan produktivitas. Produktivitas meningkat karena adanya 
komitmen. Task commitment ada selama individu merasakan bahwa ia terhubung ke tugas tersebut (Elias, 1985). Dubin mengemukakan bahwa Task commitment memiliki tiga aspek, yaitu 1) keinginan yang kuat untuk tetap mengerjakan tugas; 2) kemauan untuk mengerahkan usaha secara maksimal; dan 3) keyakinan yang kuat dan penerimaan nilai-nilai dan tujuan yang ingin dicapai dalam mengerjakan tugas (Elias, 1985).

Selain itu, seperti yang telah dikemukakan bahwa task commitment merupakan perwujudan dari motivasi internal, maka hal-hal yang memengaruhi motivasi juga memengaruhi task commitment seperti 1) prestasi, suatu keinginan untuk memperjuangkan tugas dan melibatkan usaha individu dalam menghadapi tantangan; 2) pengakuan, individu akan merasa dihargai apabila ia dilibatkan dalam menyelesaikan tugas yang penting; 3) pekerjaan itu sendiri, individu merasa pekerjaan yang ada adalah sesuatu yang menantang; 4) tanggung jawab, keinginan agar dapat mengerjakan tugas dengan baik. Hal ini berarti bahwa individu dituntut untuk mandiri agar dapat melakukan tugas dan tanggung jawab yang diharapkan; 5) kemajuan, individu merasakan kemajuan dari tugas yang dikerjakannya; dan 6) perkembangan yang meliputi segala aspek internal dan eksternal yang ada di lingkungan individu dapat memengaruhi kinerja individu (Ghufron \& Risnawita, 2011).

Kemandirian adalah kemampuan untuk mengendalikan, mengatur pikiran, perasaan, dan tindakan sendiri secara bebas serta berusaha sendiri untuk mengatasi perasaan malu dan ragu-ragu (Desmita, 2014). Kemandirian adalah kemampuan untuk mengatur diri sendiri, mengambil keputusan sendiri yang disertai dengan tanggung jawab dan mampu untuk menyesuaikan tindakannya untuk mencapai suatu tujuan (Johnson, 2014).

Kemandirian individu terlihat dari kemampuannya dalam berpikir dan bertindak. Kemandirian membuat individu lebih berhasil dalam mengerjakan sesuatu yang memberikan lebih banyak kesempatan berpikir dan melakukan halhal yang diminati. Kemandirian mampu mendorong motivasi yang kuat untuk berprestasi dalam situasi yang memberikan kebebasan (Ghufron \& Risnawita, 2011). Kemandirian merupakan suatu kondisi ketika individu memiliki hasrat bersaing untuk maju demi kebaikannya sendiri, dapat mengambil keputusan, memiliki inisiatif untuk mengatasi masalah, percaya diri dan bertanggung jawab dalam melaksanakan tugas (Desmita, 2014).

Kemandirian adalah tentang kebebasan, sikap independen, dan pilihan. Hal ini juga menyangkut tantangan yang dihadapi individu yang berusaha untuk memahami dan menyelesaikan masalahmasalah rumit. Setiap individu senantiasa dihadapkan pada pilihan-pilihan yang dapat memengaruhi di setiap aspek kehidupan. Pilihan yang ada, membuat individu perlu mengatur hal-hal yang dianggap penting dan mengesampingkan pilihan yang kurang layak. Hal ini tidak menuntut individu untuk terikat pada rutinitas yang membosankan sehingga memungkinkan individu untuk terbuka pada ide-ide dan pengalaman baru. Kemampuan untuk menentukan keseimbangan ini, memiliki implikasi penting untuk kebahagiaan, kesejahteraan, dan kualitas hidup (Brockett, 2006).

Ada tiga hal yang menjadi sumber kemandirian yaitu 1) bersikap independen, menolak aturan; 2) bebas untuk mengaktualisasikan dirinya dan memiliki 
konsep diri; 3) dan kemampuan untuk mengendalikan, berkuasa untuk mengontrol dirinya sendiri (Gelderan, Jansen, \& Jonges, 2003).

Kemandirian memiliki tiga aspek yaitu: 1) mengambil inisiatif untuk bertindak dan mengendalikan aktivitas yang dilakukan. Individu yang mandiri, menyadari sesuatu yang penting dan hal yang menjadi tugas dan tanggung jawabnya, kemudian melaksanakannya atas kemauan sendiri, tanpa paksaan atau menunggu perintah dari orang lain. Individu yang mandiri tidak terikat pada orang lain di dalam melakukan kegiatan; 2) memberdayakan kemampuan yang dimiliki. Individu yang mandiri cenderung mempercayai dan memanfaatkan secara maksimal kemampuan-kemampuan yang dimiliki di dalam menjalankan tugas, mengambil keputusan atau memecahkan masalah, tanpa banyak berharap pada bantuan atau pertolongan orang lain. Ketika menemui kendala dalam bertugas, individu yang mandiri berusaha untuk mengatasi sendiri. Setelah berusaha namun masih tetap gagal, dengan terpaksa ia meminta bantuan pada orang lain; dan 3) menghargai hasil kerja sendiri. Individu yang mandiri merasa puas atas apa yang telah dihasilkan sendiri, termasuk karya-karya sederhana sekalipun. Hal ini disebabkan individu telah memberdayakan sejumlah kemampuan yang dimiliki baik berupa tenaga maupun pikiran, bahkan sejumlah materi tanpa melibatkan bantuan dari orang lain di dalam proses bekerja (Suharnan, 2012).

Merantau adalah salah satu bentuk dari adanya kemandirian (Anggraini, 2014). Selain itu, penelitian Ma'asy (2015), menunjukkan bahwa perantau suku Bugis dapat menerapkan tiga komponen yang dimilikinya saat berada di perantauan. 1) Komponen pengetahuan, para perantau
Bugis tahu akan diri dan kedatangannya, sehingga ia berusaha menempatkan diri dalam kondisi kebudayaan yang berbeda dan secara perlahan dan bisa berbaur atau menyatu dengan budaya suku asli; 2) Komponen kesadaran, kesadaran yang dimiliki perantau Bugis sangatlah baik, ia mencoba untuk menempatkan diri secara tepat agar tidak terjadi perselisihan dengan suku asli di perantauan, dengan cara mengenalkan cara kehidupannya, baik dari segi makanan, rumah, pakaian dan bahasa serta kesenian; 3) Komponen kemampuan, kemampuan yang dimiliki perantau Bugis mampu membawanya ke arah yang lebih baik, sehingga ia mampu menghormati, memahami, dan menghargai suku asli di perantauan.

Berdasarkan penjelasan di atas, dapat diketahui bahwa kemandirian merupakan hal yang sangat penting karena dapat memengaruhi kemampuan task commitment individu menjadi lebih baik sehingga hal tersebut menarik minat peneliti untuk mengkaji lebih dalam mengenai task commitment pada mahasiswa perantau yang berasal dari suku Bugis, yang identik dengan keberaniannya dalam berjuang di perantauan. Oleh karena itu, penelitian ini bertujuan untuk mengetahui pengaruh kemandirian terhadap task commitment mahasiswa suku Bugis yang merantau. Adapun hipotesis dalam penelitian ini yaitu kemandirian berpengaruh terhadap task commitment pada mahasiswa suku Bugis yang merantau.

\section{Metode}

Jenis penelitian yang digunakan adalah penelitian kuantitatif yang terdiri dari dua variabel. Penelitian ini bertujuan untuk mengetahui pengaruh kemandirian terhadap task commitment pada mahasiswa suku Bugis yang merantau. Subjek dalam 
penelitian ini adalah mahasiswa yang berasal dari suku Bugis dan sedang melanjutkan pendidikan di perantauan. Teknik pengambilan sampel dilakukan secara random dengan kriteria mahasiswa suku Bugis dan merantau. Berdasarkan hasil penyebaran skala penelitian melalui google form, diperoleh sebanyak 96 subjek penelitian.

Peneliti menggunakan instrumen berupa skala untuk mengukur task commitment dan kemandirian mahasiswa perantau suku Bugis. Peneliti memodifikasi skala task commitment dari Frederick George Elias untuk mengukur task commitment yang terdiri atas tiga aspek, yaitu 1) keinginan yang kuat untuk tetap mengerjakan tugas; 2) kemauan untuk mengerahkan usaha secara maksimal; dan 3) keyakinan yang kuat dan penerimaan nilai-nilai dan tujuan yang ingin dicapai dalam mengerjakan tugas. Skala task commitment terdiri atas 21 aitem dengan reliabilitas 0,815 cronbach alpha.

Peneliti menggunakan skala kemandirian dari Suharnan untuk mengukur kemandirian yang terdiri atas tiga aspek, yaitu 1) mengambil inisiatif untuk bertindak dan mengendalikan aktivitas yang dilakukan; 2) memberdayakan kemampuan yang dimiliki; dan 3) menghargai hasil kerja sendiri. Skala kemandirian terdiri atas 43 aitem dengan reliabiltias 0,943 cronbach alpha.

Analisis data menggunakan teknik analisis regresi untuk menguji hipotesis yang diajukan dalam penelitian ini yaitu pengaruh kemandirian terhadap task commitment pada mahasiswa suku Bugis yang merantau. Sebelum melakukan pengujian hipotesis menggunakan analisis regresi, terlebih dahulu dilakukan uji korelasi untuk mengetahui apakah terdapat hubungan diantara kedua variabel. Jika terdapat hubungan antara kedua variabel, maka dapat dilanjutkan menggunakan analisis regresi.

\section{Prosedur penelitian}

Adapun tahapan prosedur dalam penelitian ini, terbagi dalam tiga tahapan, yaitu: 1) Tahap persiapan, peneliti mempersiapkan alat ukur yang telah dinyatakan reliabel dan memenuhi syarat sebagai instrumen penelitian; 2) Tahap pengumpulan data, peneliti menggunakan bantuan google form untuk menyebarluaskan instrumen penelitian kepada mahasiswa suku Bugis yang melanjutkan pendidikan di perantauan. Proses pengumpulan data berlangsung dari bulan oktober 2016 hingga bulan april 2017; 3) Tahap analisis data, peneliti melakukan analisis data terhadap data penelitian dengan menggunakan bantuan IBM SPSS Statistics 21.

\section{Hasil}

Hasil statistik deskriptif dapat dilihat pada Tabel 1. Sementara itu, hasil kategorisasi kemandirian dan task commitment yang dimiliki mahasiswa suku Bugis yang merantau dapat dilihat pada Tabel 2.

Tabel 1.

Deskripsi data empirik dan hipotetik penelitian

\begin{tabular}{|c|c|c|c|c|c|}
\hline \multicolumn{6}{|c|}{ Data Empirik } \\
\hline Variabel & $\mathrm{N}$ & Mean & SD & Min & Max \\
\hline Kemandirian & 96 & 165,55 & 20,799 & 117 & 214 \\
\hline $\begin{array}{c}\text { Task } \\
\text { Commitment }\end{array}$ & 96 & 80,34 & 8,836 & 54 & 99 \\
\hline \multicolumn{6}{|c|}{ Data Hipotetik } \\
\hline Variabel & $\mathrm{N}$ & Mean & SD & Min & Max \\
\hline Kemandirian & 96 & 129 & 29 & 43 & 215 \\
\hline $\begin{array}{c}\text { Task } \\
\text { Commitment }\end{array}$ & 96 & 63 & 14 & 21 & 105 \\
\hline
\end{tabular}


Tabel 2

Kategorisasi variabel penelitian

\begin{tabular}{|c|c|c|c|}
\hline \multicolumn{4}{|c|}{ Kategorisasi Kemandirian } \\
\hline Norma & Kategori & Frekuensi & $\%$ \\
\hline $158 \leq X$ & Tinggi & 58 & 60,41 \\
\hline $100 \leq X<158$ & Sedang & 38 & 39,58 \\
\hline$X<100$ & Rendah & 0 & 0 \\
\hline \multicolumn{4}{|c|}{ Kategorisasi Task Commitment } \\
\hline Norma & Kategori & Frekuensi & $\%$ \\
\hline $77 \leq X$ & Tinggi & 60 & 62,5 \\
\hline $49 \leq X<77$ & Sedang & 36 & 37,5 \\
\hline$X<49$ & Rendah & 0 & 0 \\
\hline
\end{tabular}

\section{Hasil uji hipotesis}

Berdasarkan hasil uji korelasi product moment, diperoleh nilai korelasi sebesar 0,625 dengan sign. 0,000 $<0,05$ sehingga dapat disimpulkan bahwa terdapat hubungan yang positif antara kemandirian dan task commitment pada mahasiswa suku Bugis yang merantau. Oleh karena itu, dapat dilanjutkan menggunakan analisis regresi. Hasil analisis regresi menunjukkan nilai $F$ sebesar 60,267 dengan sign. $0,000<0,05$ sehingga dapat disimpulkan bahwa kemandirian berpengaruh terhadap task commitment yang dimiliki mahasiswa suku Bugis yang merantau. Sementara itu, $R$ square menunjukkan nilai sebesar 3,91, yang berarti bahwa task commitment dipengaruhi oleh kemandirian sebesar 39,1\% dan selebihnya dipengaruhi oleh faktor lain.

\section{Diskusi}

Hasil analisis data menunjukkan bahwa kemandirian memiliki pengaruh terhadap task commitment mahasiswa suku Bugis yang merantau. Kekuatan hubungan antar variabel kemandirian dan task commitment ditunjukkan dengan nilai korelasi sebesar 0,625 . Hal tersebut menunjukkan bahwa hubungan antara kedua variabel tersebut tergolong kuat. Sementara itu, variabel kemandirian memiliki sumbangan efektif terhadap variabel task commitment sebesar $39,1 \%$ sehingga dapat disimpulkan bahwa kemandirian berpengaruh terhadap task commitment mahasiswa suku Bugis yang merantau. Nashori (Warsito, 2013) mengemukakan bahwa salah satu ciri kualitas hidup yang berperan penting dalam kesuksesan seseorang adalah dengan memiliki pribadi yang mandiri. Hasil penelitian ini sejalan dengan penelitian yang dilakukan Solihin (2013) yang menunjukkan bahwa perantau suku Bugis memiliki kegigihan dalam bertahan hidup dan beradaptasi di lingkungan baru.

Hasil penelitian ini mengindikasikan adanya task commitment yang tinggi yang dimiliki oleh mahasiswa suku Bugis yang merantau. Selain itu, berdasarkan wawancara dengan lima orang mahasiswa suku Bugis yang menjadi subjek dalam penelitian ini, ia merasa malu untuk pulang ke daerah jika apa yang dicitacitakannya sejak pertama kali merantau belum berhasil ia capai. Dalam budaya Bugis, hal tersebutlah yang patut dipegang teguh karena berkaitan erat dengan martabat sebagai orang yang berasal dari suku Bugis. Dalam budaya Bugis, rasa malu tersebut dinamakan sebagai siri'. Budaya siri' yang dipegang teguh dalam perantauan bermakna sebagai adanya rasa malu jika mahasiswa rantau harus pulang ke daerah tanpa membawa hasil. Oleh karena itu, mahasiswa yang merantau memegang teguh prinsip yang dianutnya (Raseya, 2013). Pelras (2006) mengemukakan bahwa konsep siri' dapat digunakan sebagai kunci utama untuk memahami berbagai aspek perilaku sosial orang Bugis. Misalnya bila seorang lelaki dalam suatu keluarga berhasil meraih suatu prestasi, maka saudara laki-lakinya akan berusaha mencapai sesuatu yang lebih baik, demi siri'nya sendiri. Kondisi 
tersebut memiliki arti penting sebagai pendorong dilakukannya suatu usaha atau pergi merantau dalam rangka mencapai keberhasilan di bidang akademik.

Selain budaya siri', menurut kelima orang mahasiswa yang penulis wawancarai, ia mengatakan bahwa dalam budaya Bugis, dikenal pula semboyan "sekali layar terkembang, pantang biduk surut ke pantai". Hal tersebut mengindikasikan bahwa mahasiswa suku Bugis yang merantau akan berusaha dengan maksimal untuk memperoleh apa yang menjadi tujuannya dan akan menghadapi apapun yang menjadi rintangan dalam upaya mencapai tujuannya. Mahasiswa suku Bugis akan merasa sangat malu dan gagal bila ia pulang ke daerah tanpa membawa hasil. Hal tersebut menyangkut dengan harga dirinya sebagai manusia. Bagi suku Bugis, lebih baik mati daripada harus hidup dengan menanggung malu. Oleh karena itu, mahasiswa suku Bugis yang merantau, akan tetap menunjukkan komitmennya dalam mencapai tujuan, meskipun memiliki banyak rintangan (Rayesa, 2013).

Penelitian yang dilakukan oleh Kim, Byeon, dan Kwon (2012) menunjukkan bahwa terdapat lima jenis task commitment yang dimiliki mahasiswa yaitu task goal commitment, low goal commitment, 3) conditional commitment, suspended commitment, dan delayed commitment. Pada penelitian ini terlihat bahwa mahasiswa suku Bugis yang merantau menunjukkan task goal commitment, yaitu komitmen pada tujuan yang telah ditetapkan dengan harapan yang tinggi.

Selain itu, kemandirian dan task commitment yang dimiliki mahasiswa suku Bugis yang merantau memiliki mean sebesar 165,55 dan 80,34. Kedua mean tersebut berada pada kategori yang tinggi. Hasil penelitian ini sesuai dengan yang dikemukakan oleh Dubin (Elias, 1985) bahwa individu yang memiliki task commitment maka ia akan menunjukkan keinginan yang kuat untuk tetap mengerjakan tugas; kemauan untuk mengerahkan usaha secara maksimal dan 3) keyakinan yang kuat dan penerimaan nilai-nilai dan tujuan yang ingin dicapai dalam mengerjakan tugas. Sementara itu, menurut Suharnan (2012) bahwa individu yang mandiri adalah individu yang mampu mengambil inisiatif untuk bertindak dan mengendalikan aktivitas yang dilakukan, memberdayakan kemampuan yang dimiliki, dan menghargai hasil kerja sendiri.

Kelebihan mahasiswa rantau adalah ia dapat belajar hidup mandiri dan bersosialisasi dengan lingkungan barunya dibandingkan dengan mahasiswa yang tinggal bersama orang tuanya (Winata, 2014). Selain itu, dengan didasari oleh keinginan untuk mendapatkan pendidikan terbaik yang biasanya tidak didapatkan di daerah asal, menyebabkan orang merantau untuk mendapatkan kualitas pendidikan yang lebih baik (Irene, 2013). Tingkat kemandirian mahasiswa suku Bugis $60,41 \%$ berada pada kategori tinggi, 39,58\% berada pada kategori sedang, dan $0 \%$ berada pada kategori rendah. Sementara itu, tingkat task commitment mahasiswa suku Bugis $62,5 \%$ berada pada kategori tinggi, 37,5\% berada pada kategori sedang, dan $0 \%$ berada pada kategori rendah. Oleh karena itu, dapat disimpulkan bahwa hasil penelitian ini menunjukkan bahwa mahasiswa suku Bugis yang merantau memiliki tingkat kemandirian dan task commitment yang tinggi.

\section{Kesimpulan}

Kemandirian berpengaruh terhadap task commitment yang dimiliki mahasiswa suku Bugis yang merantau. Task commitment yang tinggi disebabkan karena keman- 
dirian yang dimiliki mahasiswa di perantauan. Adanya nilai-nilai budaya yang dianut oleh mahasiswa suku Bugis seperti yang dikenal dengan istilah siri' (rasa malu) dan semboyan yang dimiliki suku Bugis yaitu "sekali layar terkembang, pantang biduk surut ke pantai", turut menjadi faktor yang menguatkan task commitment pada mahasiswa suku Bugis yang merantau.

\section{Saran}

Adapun saran dari penelitian ini yaitu, bagi peneliti selanjutnya agar melakukan penelitian secara kualitatif untuk mendalami proses dinamika psikologis yang terjadi pada mahasiswa suku Bugis yang merantau sehingga dapat diuraikan sejauhmana nilai-nilai budaya yang dianut mahasiswa terinternalisasi dalam dirinya.

\section{Kepustakaan}

Anggraini, N. E. (2014). Hubungan antara kemandirian dengan penyesuaian diri pada mahasiswa baru yang merantau di kota Malang. Jurnal Psikologi Universitas Brawijaya Malang, 1, 1-11.

Brockett, R. G. (2006). Self-directed learning and the paradox of choice. International Journal of Self-directed Learning, 3(2), 27-33.

Desmita. (2014). Psikologi perkembangan peserta didik. Bandung: Remaja Rosdakarya.

Elias, F. G. (1985). Task-focused selfdisclosure: Effects on group cohesiveness, commitment to task and group productivity. Dissertation Santa Barbara: University of California.

Firmanto, A. (2013). Kecerdasan, kreativitas, task commitment, dan jenis kelamin sebagai prediktor prestasi hasil belajar. Jurnal Sains dan Praktik
Psikologi, 1(1), (Online), (https:// ejournal.umm.ac.id, diakses tanggal 9 Oktober 2016).

Fleming, M. (2005). Adolescent autonomy: Desire, achievement and disobeying parents between early and late adolescence. Australian Journal of Education and Developmental Psychology, 5, 1- 16.

Gelderan, M., Jansen, P., \& Jonges, S. (2003). The multiple sources of autonomy as a startup motive. Research Report. Netherlands: EIM.

Ghufron, M. N., \& Risnawita S. R. (2011). Teori-teori psikologi. Jogjakarta: ArRuzz Media.

Irene, L., \& Warsito, H. (2013). Perbedaan tingkat kemandirian dan penyesuaian diri mahasiswa perantauan suku Batak ditinjau dari jenis kelamin. Character: Jurnal Penelitian Psikologi, 1(2), 1-10.

Johnson, E. B. (2014). CTL: Contextual teaching \& learning, menjadikan kegiatan belajar-mengajar mengasyikkan dan bermakna. Bandung: Kaifa.

Kim, W. J., Byeon, J. H, \& Kwo, Y. J. (2012). Analysis of task commitment types of science learning in high school students' biology classification. J Korea Assoc. Sci. Edu., 32(6), 863-879.

Ma'asy, M. R. (2015). Komunikasi antar budaya perantau Bugis dengan etnis Kutai di samarinda seberang. Journal Ilmu Komunikasi, 3(4), 282-295.

Pelras, C. (2006). Manusia bugis. (Cetakan ke-1). Jakarta: Nalar-Forum JakartaParis.

Rayesa. (2013). Sekali layar terkembang pantang biduk surut ke pantai-keberanian yang penuh perhitungan dan kearifan (kualleangi tallanga natowalia). (Online), (https://rayesablog.wordpress.com/201 
3/03/28/sekali-layar-terkembangpantang-biduk-surut-ke-pantai/, diakses 8 Oktober 2016).

Santrock, J. W. (2007). Psikologi pendidikan. (Edisi 2). Jakarta: Kencana.

Scott, K. W. (2006). Self-directed learners' concept of self as learner: Congruous autonomy. International Journal of Selfdirected Learning, 3(2), 1-13.

Shafira, F. (2015). Hubungan antara kematangan emosi dengan penyesuaian diri pada mahasiswa perantau. Skripsi. Surakarta: Fakultas Psikologi, Universitas Muhammadiyah Surakarta.

Solihin, L. (2013). Mereka yang memilih tinggal: Telaah strategi adaptasi mahasiswa perantau Bugis-Makassar di Melbourne, australia. Jurnal Pendidikan dan Kebudayaan, 19(2), 252-267.

Suharnan. (2012). Pengembangan skala kemandirian. Persona, Jurnal Psikologi Indonesia, 1(2), 66-76.

Syarifah, A., Mustami'ah, D., \& Sulistiani, W. (2011). Hubungan antara dukungan sosial orang tua dengan komitmen terhadap tugas (task commitment) pada siswa akselerasi tingkat SMA. Jurnal Psikologi Insan Media, 13(1), 1-11.

Tiel, J. M., \& Widyorini, E. (2014). Deteksi dan penanganan anak cerdas istimewa (anak gifted): Melalui pola alamiah tumbuh kembangnya. Jakarta: Prenada.

Vaidya, S. (2012). Trust and commitment: Indicators of successful learning in international joint ventures (IJVS). Journal of Comparative International Management, 15(1), 29-49.

Warsito, W. S. H. (2013). Perbedaan tingkat kemandirian dan penyesuaian diri mahasiswa perantauan suku batak ditinjau dari jenis kelamin. Jurnal Psikologi Character, 1(2), 1-6.

Wijaya, B. O. (2015). Hubungan antara penyesuaian diri dengan kemandirian pada mahasiswa yang merantau Fakultas Teknik Industri Universitas Bina Darma angkatan 2014/2015 Palembang. Jurnal Fakultas Psikologi Universitas Bina Darma Palembang, 1-14.

Winata, A. (2014). Adaptasi sosial mahasiswa rantau dalam mencapai prestasi akademik. Skripsi (tidak dipublikasikan). Bengkulu: Jurusan Ilmu Kesejahteraan Sosial, Fakultas Ilmu Sosial dan Ilmu Politik, Universitas Bengkulu. 